\title{
Essays and Trials: Foreword
}

Marta Dvorak

\section{(2) OpenEdition}

1 Journals

Electronic version

URL: https://journals.openedition.org/ces/8564

DOI: 10.4000/ces.8564

ISSN: 2534-6695

\section{Publisher}

SEPC (Société d'études des pays du Commonwealth)

\section{Printed version}

Date of publication: 1 September 2009

Number of pages: 2

ISSN: 2270-0633

\section{Electronic reference}

Marta Dvorak, "Essays and Trials: Foreword", Commonwealth Essays and Studies [Online], 32.1 | 2009,

Online since 23 December 2021, connection on 17 February 2022. URL: http://

journals.openedition.org/ces/8564 ; DOI: https://doi.org/10.4000/ces.8564

\section{(c) (i) () $\Theta$}

Commonwealth Essays and Studies is licensed under a Licence Creative Commons Attribution - Pas d'Utilisation Commerciale - Pas de Modification 4.0 International. 


\section{FOREWORD}

This issue is devoted to the protean genre of the essay, deployed in both scientific and literary discourse in often fluid, hybrid ways. Its potential to take on multiple forms of interstitiality allows it to interrogate concerns at the heart of both postcolonialism and postmodernism, namely the conjunctive and disjunctive relations of authority and authorship, and the dynamics of derivation, transformation, and deviation.

Commonwealth Essays and Studies 32.1 is a theme issue based on the SAES Congress in Bordeaux, France, and we gratefully acknowledge the support of the SAES, whose funding has contributed to bringing this issue to press.

Marta DVORAK

Editor 